University for Business and Technology in Kosovo

UBT Knowledge Center

UBT International Conference

2017 UBT International Conference

Oct 28th, 9:00 AM - 10:30 AM

\title{
Trends of the Contraceptive Medicine Consumption in Kosovo
}

\author{
Arianit Jakupi \\ University for Business and Technology, arianit.jakupi@ubt-uni.net \\ Shpend Dragusha \\ University for Business and Technology \\ Valon Ejupi \\ University for Business and Technology \\ Eda Mehmeti \\ University for Business and Technology \\ Agon Hoti \\ University for Business and Technology
}

Follow this and additional works at: https://knowledgecenter.ubt-uni.net/conference

Part of the Medicine and Health Sciences Commons

\section{Recommended Citation \\ Jakupi, Arianit; Dragusha, Shpend; Ejupi, Valon; Mehmeti, Eda; and Hoti, Agon, "Trends of the Contraceptive Medicine Consumption in Kosovo" (2017). UBT International Conference. 284. \\ https://knowledgecenter.ubt-uni.net/conference/2017/all-events/284}

This Event is brought to you for free and open access by the Publication and Journals at UBT Knowledge Center. It has been accepted for inclusion in UBT International Conference by an authorized administrator of UBT Knowledge Center. For more information, please contact knowledge.center@ubt-uni.net. 


\title{
Trends of the Contraceptive Medicine Consumption in Kosovo
}

\author{
Arianit Jakupi ${ }^{1}$, Eda Mehmeti ${ }^{1}$, Shpend Dragusha ${ }^{1}$, Valon Ejupi ${ }^{1}$, Agon Hoti $^{1}$ \\ ${ }^{1}$ Faculty of Pharmacy, UBT College, Lagjja Kalabria, p.n., Prishtinë, Kosovë \\ arianit.jakupi@ubt-uni.net
}

\begin{abstract}
One of the main objectives of this research was to obtain the data about the consumption of contraceptive medicines in Kosovo, and to compare to other European countries with drug utilization studies and to try to understand the rationale about the obtained results while also measuring progress towards the WHO Millennium Development Goals and Kosovo Health Sectorial Strategy 2017-2021. Regarding the contraceptive medicine consumption it is used the ATC classification of and the Defined Daily Doses per inhabitant per day (DID) as a numeric tool of the analysis. As for the perception of contraceptive dispensing in retail pharmacies are conducted interviews with pharmacists and for the prescription with doctors as part of the qualitative research with predefined questioners with open ended questions. There are analyzed all drugs of the G Group (Genitourinary system and sex hormones) in Kosovo from 2011 to 2015. From the medicines consumption data, it is seen that for the G-Group there is in general increasing trend of the total consumption in DID from 4.26 DID in 2011 to 10.52 DID in 2015. In the detailed analysis for the contraceptives subgroup G03A - Hormonal contraceptives for systemic use and G03D - Progestogens are the most consumed with 2.78 DID respectively 2.91 DID for the five year period 2011-2015. Kosovo is among the countries with very low contraception medicine consumption compared to other European and neighboring countries, which have much more consumption of this class of medicines as in Croatia with annual average of 36.12 DID, Montenegro 24.2 DID, Serbia 40.5 DID, Estonia 52.17 DID, Latvia 32.67 DID, Lithuania 28.72 DID. These data show the entire group G, however also the subgroup analysis show similar comparison. From the interviews with pharmacists and doctors it can be concluded that there is a low budget for providing and covering all the needs, there is lack of education for the benefits of the contraception use although the UNFPA has done a lot on this regard, but there are also a cultural, economic, and social factors for which Ministry of Health should make more awareness campaigns and fulfill the requirements from the health sectorial strategy.
\end{abstract}

Keywords: medicine, contraceptive consumption, hormones, ATC.

\section{Introduction}

In the period of puberty in adults is started the production of steroid sexual hormones which are responsible for the maturation of reproducing organs, development of sexual secondary characteristics and closing of the bones epiphyses (1). Sexual hormones produced by the gonads and adrenals are necessary for conception, embryonic maturation and development of primary and secondary sexual characteristics at puberty, while later the gonadal hormones are used therapeutically in replacement therapy and in the case of estrogen for contraception and osteoporosis (2). As we see that there are different indication for use of these products while there are no useful official data in Kosovo about their use and prescribing patterns.

Kosovo Hospital University and Clinical Service is a functional unit that manages all the hospitals in Kosovo including the University Clinical Centre of Kosovo. In these hospitals exist Gynecology and obstetrics clinics that deal with the kind of patients in need for these particular 
hormone therapies. With the increase in life span that is expected in the 1990s, one third or more of a woman's life may occur after menopause and the benefits of and guidelines for estrogen replacement therapy have been well established for postmenopausal women (3).

Drug consumption data show the entire consumption of medicines and based on the ATC methodology that can easily detect the hormones and sex hormones as well as subgroups in different levels of the ATC classification system. However these data do not show for what indication are these medicines used and what are the prescribing patterns. With these data as main drug utilization tool could be used to compare results with different countries particular those that are neighboring with which we share similarities and for which the comparison could be more realistic. The ATC - DDD methodology gives this opportunity while the other results that will be obtained from the qualitative methodology will clarify other aimed indicators for the research objectives.

Non-contraceptive health benefits of oral contraceptives include: Prevention of osteoporosis, ovarian and endometrial cancer prevention, other suggested benefits of oral contraceptives (protection against benign breast disease, ectopic pregnancy, salpingitis, dysmenorrhea and iron deficiency anemia) (3). This is another fact that the use of these group of medicines is not limited only to contraception but mostly for the keeping the hormonal balance, giving in this way also the benefit for the above mentioned conditions. The most used cases for prescribing the hormonal therapy include the control of reproduction, prevention or assisting conception, treatment of symptoms related to osteoporosis, treatment of estrogen deficiency, thromboembolism etc. (1). This shows that there are different indications that are related to this class of medicines while the prevalence, incidence and prescribing patterns in Kosovo are not well described.

There are a lot of studies in Kosovo about the reproductive health done from UNFPA that has been advocating for the reproductive health and rights of every woman, man and child, individually and as families, since 1999 in partnership with government, NGOs, communities, and other UN agencies, UNFPA Kosovo has worked to achieve its goals (4).

In a study published by Ministry of Public Administration in 2009 it is stated that rates of ever use and current use of effective, modern methods are very low, and use of pills and IUDs and rhythm were each lower in 2009 than in 2003 or 1999-2000 while the decline in the use of modern methods of contraception may reflect the fact that there is now less donor involvement in reproductive health in Kosovo than there was in 2003 (5). In the same report it is stated that the low (and decreasing) rate of use of effective methods of contraception and the reliance of Kosovar women on the relatively ineffective method of withdrawal are causes for concern while it is recommended that efforts should be made to increase the use of effective methods of contraception.

Another fact that is also important for this study is that there is lack of diagnostic procedures hence also the lower use of medicines including also hormonal therapy. According to Knowles and Packer (2009) Many cervical and breast cancer cases in Kosovo remain undiagnosed and untreated and conclude that there is hidden burden of disease amongst women who live and die with their disease, lacking even basic medical or social intervention or support. (6)

According to Basha V and Hutter I (2006) in a qualitative study made in Kosovo obtained outcomes from the focus group discussions that show a strong awareness of contraceptive methods, at least the IUD and pills, and they think that this knowledge is based on what participants heard from others, not on information that they received directly themselves, either from medical people or other professionals. In a same study they found that Intra Uterine Device (IUD) is the most talked about contraceptive method by participants, especially older women while the IUD is also the contraceptive that is mostly recommended by gynecologists. (7)

\section{Objectives}

One of the main objectives of this research is to obtain data about the consumption of contraceptive medicines in Kosovo, compare to other European countries with drug utilization 
studies and try to understand the rationale about the obtained results especially for the mostly used medicines according to their indication and understanding prescribing patterns in Kosovo.

\section{Materials and methods}

Initially the consumption of this group of medicines is consulted from the report of the drug consumption 2011-2013 and other obtained data from the MoH and Kosovo Medicines Agency. Regarding the contraceptive medicine consumption it is used the ATC classification of and the Defined Daily Doses per inhabitant per day (DID) as a numeric tool of the analysis.

According to WHO in the Anatomical Therapeutic Chemical (ATC) classification system, the active substances are divided into different groups according to the organ or system on which they act and their therapeutic, pharmacological and chemical properties, furthermore explaining that drugs are divided into fourteen main groups (1st level), with pharmacological/therapeutic subgroups (2nd level), the 3rd and 4th levels are chemical/pharmacological/therapeutic subgroups and the 5th level is the chemical substance (8).

Furthermore were introduced DDD (Defined Daily Dose - as the average maintenance daily dose of a product) and DID (Defined Daily Dose of a product per Inhabitant per Day) which are used for drug utilization studies and also that are used in the analysis for this paper (9).

As for the perception of contraceptive dispensing in retail pharmacies are conducted interviews with pharmacists and for the prescription with doctors as part of the qualitative research with predefined questioners with open ended questions.

\section{Results}

There are analyzed medicines of the group G according to the ATC classification, with marketing authorization in Kosovo which include 46 medicines according to their INN name for all this class in 96 different pharmaceutical forms and dosages and from 52 different manufacturing sites from 23 different countries (10).

From the general medicines consumption data it is seen that the $\mathrm{G}$ group is in the lower part of the table the $9^{\text {th }}$ from 14 groups in total, showing that the consumption of these medicines is only $1.67 \%$ of the total consumption considering the DID percentage (table 1). 
Table 1 Consumption of Medicines in Kosovo in DID (Source: Kosovo Medicines Agency 2014.)

\begin{tabular}{|c|c|c|c|c|c|}
\hline ATC 1 & 2011 & 2012 & 2013 & Total & $\%$ \\
\hline $\mathrm{C}$ & 86.36 & 97.13 & 110.06 & 293.55 & $32.69 \%$ \\
\hline B & 32.04 & 51.91 & 57.23 & 141.18 & $15.72 \%$ \\
\hline A & 41.73 & 41.44 & 50.14 & 133.3 & $14.84 \%$ \\
\hline M & 25.33 & 35.92 & 30.06 & 91.3 & $10.17 \%$ \\
\hline $\mathrm{N}$ & 26.41 & 22.42 & 25.5 & 74.33 & $8.28 \%$ \\
\hline $\mathrm{J}$ & 24.45 & 26.81 & 19.62 & 70.88 & $7.89 \%$ \\
\hline $\mathrm{R}$ & 23.21 & 14.43 & 17.32 & 54.96 & $6.12 \%$ \\
\hline $\mathrm{H}$ & 7.58 & 5.94 & 7.03 & 20.54 & $2.29 \%$ \\
\hline $\mathrm{G}$ & 4.81 & 3.34 & 6.85 & 15 & $1.67 \%$ \\
\hline $\mathrm{L}$ & 0.96 & 0.48 & 0.4 & 1.84 & $0.20 \%$ \\
\hline$S$ & 0.58 & 0 & & 0.58 & $0.06 \%$ \\
\hline $\mathrm{D}$ & 0.32 & 0.01 & 0.04 & 0.38 & $0.04 \%$ \\
\hline $\mathrm{P}$ & 0.04 & 0.03 & 0.01 & 0.08 & $0.01 \%$ \\
\hline $\mathrm{V}$ & 0 & 0 & 0.02 & 0.03 & $0.00 \%$ \\
\hline Total & 273.81 & 299.86 & 324.28 & 897.95 & $100.00 \%$ \\
\hline
\end{tabular}

However the consumption of medicines not only in DID can be compared also for its importance of the monetary values and its importance for the market from the turnover point of view and this is shown in the table 2 in the comparison the consumption as per monetary vales imported in Kosovo it is also seen that is similar to that of DID or the 9th place from 14 in total (table 2): 
Table 2 Consumption of Medicines in Kosovo in euro (Source: Kosovo Medicines

\begin{tabular}{|c|c|c|c|c|c|}
\hline & \multicolumn{4}{|c}{ Agency 2014$)$} & \\
\hline
\end{tabular}

In order to see comparison of the results and to have some picture of the $\mathrm{G}$ group medicines consumption is the results obtained from the respective medicines agencies reports as shown in table 3.

Table 3. Comparison of the group $\mathrm{G}$ consumption between countries (Source: Reports from the respective country report on consumption -see references)

\begin{tabular}{|l|c|c|}
\hline \multicolumn{1}{|c|}{ Country } & Annual DID & Consumption year \\
\hline Croatia & 36.12 & 2015 \\
\hline Montenegro & 24.20 & 2015 \\
\hline Serbia & 40.50 & 2015 \\
\hline Estonia & 55.20 & 2015 \\
\hline Latvia & 31.37 & 2015 \\
\hline Lithuania & 30.22 & 2015 \\
\hline Kosova & 6.85 & 2013 \\
\hline
\end{tabular}


If we analyze the subgroups of the ATC classification for knowing more about which particular class of medicines makes the most percentage of the consumption and thus focusing in the contraceptive medicine is shown in the table 4 as per level 3 classification of the ATC (Table 4 and 5):

Table 4 Classification of the $\mathrm{G}$ group according to the $3^{\text {rd }}$ level of the ATC (Source Kosovo Medicines Agency 2014)

\begin{tabular}{|c|c|c|c|c|c|}
\hline \multicolumn{2}{|l|}{$\begin{array}{l}\text { ATC } 3^{\text {rd }} \\
\text { level }\end{array}$} & 2011 & 2012 & 2013 & Total \\
\hline $\mathbf{G}$ & Name of the subgroup & 4.81 & 3.34 & 6.85 & 15.00 \\
\hline G04C & $\begin{array}{r}\text { Drugs used in benign prostatic } \\
\text { hypertrophy }\end{array}$ & 1.47 & 0.81 & 2.39 & 4.67 \\
\hline G01A & $\begin{array}{l}\text { Anti-infective and antiseptics, excl. } \\
\text { comb. with corticosteroids }\end{array}$ & 1.57 & 1.05 & 1.70 & 4.32 \\
\hline G03H & Antiandrogens & 0.93 & 0.20 & 1.30 & 2.43 \\
\hline G03D & Progesterons & 0.30 & 0.41 & 0.46 & 1.18 \\
\hline G01B & $\begin{array}{r}\text { Anti-infective and antiseptics, in comb. } \\
\text { with corticosteroids }\end{array}$ & 0.00 & 0.34 & 0.46 & 0.81 \\
\hline G03G & $\begin{array}{r}\text { Gonadotropins and other ovulation } \\
\text { stimulants }\end{array}$ & 0.23 & 0.21 & 0.11 & 0.55 \\
\hline G02C & Other gynecologicals & 0.11 & 0.17 & 0.20 & 0.48 \\
\hline G03A & $\begin{array}{r}\text { Hormonal contraceptives for systemic } \\
\text { use }\end{array}$ & 0.14 & 0.15 & 0.19 & 0.48 \\
\hline G04B & Urologicals & 0.00 & 0.00 & 0.04 & 0.04 \\
\hline G02A & Uterotonics & 0.04 & & & 0.04 \\
\hline
\end{tabular}


Table 5 Classification of the $\mathrm{G}$ group according to the $4^{\text {th }}$ level of the ATC (Source Kosovo Medicines Agency 2014)

\begin{tabular}{|r|r|r|r|r|r|}
\hline $\begin{array}{l}\text { ATC } \\
\text { level }\end{array}$ & \multicolumn{2}{|c|}{$\mathbf{2 0 1 1}$} & $\mathbf{2 0 1 2}$ & $\mathbf{2 0 1 3}$ & Total \\
\hline G & & $\mathbf{4 . 8 1}$ & $\mathbf{3 . 3 4}$ & $\mathbf{6 . 8 5}$ & $\mathbf{1 5 . 0 0}$ \\
\hline G01AA & Antibiotics & 0.24 & 0.16 & 0.18 & 0.58 \\
\hline G01AF & Imidazole derivatives & 1.33 & 0.88 & 1.52 & 3.74 \\
\hline G01BA & Antibiotics and corticosteroids & 0.00 & 0.34 & 0.46 & 0.81 \\
\hline G02AB & Ergot alkaloids & 0.04 & & & 0.04 \\
\hline G02CB & Prolactine inhibitors & 0.11 & 0.17 & 0.20 & 0.48 \\
\hline G03AA & Progestogens and estrogens, fixed & 0.14 & 0.15 & 0.19 & 0.47 \\
\hline G03AC & combinations & & & & \\
\hline G03DA & Progesterons & 0.00 & & & 0.00 \\
\hline G03DB & Pregnen 4 derivatives & 0.15 & 0.41 & 0.41 & 0.98 \\
\hline G03GA & Gregnadien derivatives & 0.15 & & 0.05 & 0.20 \\
\hline G03GB & Ovulation stimulants, synthetic & 0.13 & 0.16 & 0.09 & 0.38 \\
\hline G03HA & Antiandrogens plain & 0.80 & 0.10 & 1.16 & 2.05 \\
\hline G03HB & Antiandrogens and estrogens & 0.13 & 0.10 & 0.15 & 0.38 \\
\hline G04BE & Drugs used in erectile dysfunction & 0.00 & 0.00 & 0.04 & 0.04 \\
\hline G04CA & Alpha-adrenoreceptor antagonists & 1.14 & 0.67 & 2.16 & 3.98 \\
\hline G04CB & Testosterone-5-alpha reductase & 0.33 & 0.14 & 0.23 & 0.70 \\
\hline G04CX & Other drugs used in benign prostatic & & & 0.00 & 0.00 \\
\hline & hypertrophy & & & & \\
\hline & & & & \\
\hline
\end{tabular}

\section{Discussion}

In general it is seen that this class of medicines from the financial point of view is not so attractive for the companies as the total turnover is only $2.86 \%$ of the total turnover of different classes of medicines (table 2) while also if this is seen from the defined daily doses per inhabitant per day from table one we have similar figures with very low percentage of the total consumption in this case only $1.67 \%$ (table 1). Considering the fact that Kosovo is a small country, with very low budget for health and hence for pharmacy, only €21.7 milion for essential medicines in 2016 or te total consumption in 2014 approximately $€ 75$ Million Euro, figures that could mean also that there is no very big interest in registration (obtaining marketing authorization) for Kosovo. In table three it is shown the consumption of this class of medicines in different countries showing significant difference with Kosovo, while being much more similar to each - other.

Another indication for comparison is the analysis of the different levels of consumption based on ATC classification where it is seen also the proportion of the consumption of different subgroups of this class showing also the differences on that which subclass is used mostly and in this way giving a picture that where would be the lack of prescribing when comparing the same with different countries. 
This comparison can be done due to the used methodology of the ATC, DDD and DID which is used widely as a tool for drug utilization studies (9) giving the opportunity to analyze even particular substances and not just the classes and subclasses of medicines.

\section{Conclusion}

Kosovo is among the countries with very low contraception medicine consumption compared to neighboring countries and other European, which have much more consumption of this class of medicines.

- $\quad$ there is lack of education for the benefits of the contraception use

- although the UNFPA has done a lot on this regard,

- but there are also a cultural, economic, and social factors for which

Ministry of Health should make more:

- $\quad$ awareness campaigns and fulfill the requirements from the health sectorial strategy

- for the education and promotion of the healthcare as a 1 result of the strategic objective 1 of the health sectorial strategy $2017-2021$.

\section{References}

1. Rang H., Dale M., Ritter J., Flower R., (2007) Rang and Dale's Pharmacology. Churchil Livingstone, Elsevier. UK.

2. Harvey R., Champe P. (2000) Pharmacology. Lippincot Williams and Wilkins. USA.

3. Winter, J. and Matthew E. (1998) Oral Contraceptive Use During the Perimenopausal Years. Am Fam Physician. 15;58(6). p.1373-1377

4. UNFPA in Kosovo. Available from: http://kosovo.unfpa.org/en/node/9285. Accessed on 28.12.2017.

5. Demographic, social and reproductive health survey in Kosovo, (2009). Report of Ministry of Public Administration.

6. Knowles S. and Packer M (2009) Demographic, Social and Reproductive Health Survey in Kosovo. UNFPA. Ministry of Health in Kosovo

7. Vlora Basha, Inge Hutter (2006) Pregnancy and Family Planning in Kosovo. UFPA, Ministry of Health.

8. WHO (2017) Structure and Principles of ATC classification. Available from http://www.whocc.no/atc/structure_and_principles/. Accessed online on 26.11.2017.

9. WHO (2017) Introduction to drug Utilization Research. Available from: https://www.whocc.no/filearchive/publications/drug_utilization_research.pdf. Accessed online on 26.11.2017.

10. Jakupi A, Krasniqi Sh, Hoxha R, Nebija D. (2015) Drug Register 4. Kosovo Medicines Agency. Prishtina. Kosovo

11. Alims (2016) Promet i potrošnja gotovih lekova za humanuupotrebu u republici srbiji u 2015 godini. Agencija za lekove i medicinska sredstva Beograd. Srbija

12. Calims (2015) Promet i potrošnja gotovih lekova. Agencija za lekove i medicinska sredstva Crne Gore. 
13. Halmed (2016) Potrosnja lekova 2015. Available online from http://www.halmed.hr/fdsak3jnFsk1Kfa/publikacije/Potrosnja-lijekova-u-RH_20102014.pdf. Accesed on 03.12.2016.

14. Baltic Statistics on Medicines 2010-2012 :www.ravimiamet.ee/.../baltic_statistics_on_medicines_2010_2012/baltic_ statistics_on_medicines_2010_2012.pdf

15. Ravimiamet (2017) STATISTICAL YEARBOOK OF THE STATE AGENCY OF MEDICINES. Available online from: http://www.ravimiamet.ee/sites/default/files/ravimiamet_aastaraamat_a5_100lkkaaned_k3 _final.pdf. Accessed on 26.11.2017. 